\title{
CHINA IN THE SOUTH CHINA SEA. CAN CHINA'S PRESENCE IN THE SOUTH CHINA SEA LEAD TO WAR?
}

Keywords: the South China Sea, China, competition, navy, naval forces

\begin{abstract}
China has been expanding its presence on the South China Sea, which causes tensions in the region. However, when different aspects of the situation are analysed, an open armed conflict seems hardly possible. Looking at China's activity in this body of water, it appears the Chinese state strives to safeguard its interests, primarily the economic ones, nonetheless it should be emphasized that it pursues its superpower ambitions at the same time.
\end{abstract}

\section{INTRODUCTION}

In the recent years, one could observe an increasing interest in Asia with its rich history, civilisation, culture, but also with its problems, especially the conflicts that the inhabitants of this part of the world are coping with (Podsumowanie debaty..., 2018). In Polish historiography it has been particularly visible since 1990, when Janusz Rowiński signalised that war in this region may result in a global conflict (Rowiński, 1990, p.5). However, after nearly thirty years, the conflict still has not occurred, yet even presently numerous researchers and

1 Karol Kościelniak, Institute of History, Adam Mickiewicz University in Poznań; kkos@ amu.edu.pl. ORCID ID: 0000-0002-8240-5858 
experts accentuate that it is the region where the expected 'World War III' will originate. It is remarkable that the outbreak of the conflict whose repercussions are to affect the whole world has been anticipated to take place exactly in this region for such a long time. The author of this work has also reflected on this issue a number of times (Kościeniak, 2011, 2012, 2013, 2014, 2016), but he has not observed any signs that the disputes in the South China Sea were ever to bring about an open war in the region, which would spread globally. As concerns this question, we agree with the opinion of Tadeusz Iwiński, who emphasized that "[...] a nuclear conflict, or World War III, are really unlikely" talking about exactly this area and the key players during the debate "The South China Sea and the security in the Asia-Pacific region" (Podsumowanie debaty.., 2018). It seems impossible, since its coastal states have too much to lose to take part in such a hazardous game as an armed conflict with - let us put it straight - the military superpower of the region, the People's Republic of China. This is the reason why the author decided to describe the presence of the PRC on the South China Sea and its consequences; this way, we want to demonstrate that despite the expansive policy, China's activities are not attack-oriented, but aimed at securing the state's particular interests in this body of water (admittedly, at the disadvantage of others).

To begin with, the subject of the dispute will be characterised - the significance of the South China Sea to its coastal states, and it will be followed by the description of the events from the previous months (namely, years 2017-2018), showing how strong China's commitment in that body of water is. The South China Sea stretches out from the Strait of Malakka on the Southwest to the Taiwan Strait on the Northeast. It covers the area of 2,240 square kilometres, and its average depth is from 1000 to 2000 metres. Its coastal states include China, Taiwan, the Philippinest, Malaysia, Thailand, Cambodia and Vietnam. The seabed is intersected with deep trenches, between which underwater platforms are formed. When they emerge, small islands are created, e.g. around the Paracel and Spratly archipelagos. The significant feature of the South China Sea is the fact that it is the habitat for valuable fish species, and it is rich in natural gas and crude oil (O co toczy się spór..., 2015). Seafood industry and natural resources are the underlying foundation of the particularly complex international situation. In the light of the official statements made by the capitals of its coastal states, there is probably not a single centimetre of free space left in this 
sea, to which a claim has not been issued. In some parts of the sea, the claims of three, four of even five states overlap. The disputes concern the rights to the particular archipelagos, islets or reefs and atolls, the delineation of the territorial waters and exclusive economic zones, and also the size of the continental shelf, especially given the fact that in many cases it extends beyond 200 miles (according to the Montego Bay Convention on the Law of the Sea from 1982, a coastal state can delineate an exclusive economic zone extending up to 200 miles into the sea) (Kościelniak, 2014, p.11). However, the fiercest dispute concerns, above all, exercising independent authority over the Paracel Islands and the Spratly Islands. Both archipelagos are mainly composed of coral islands, with the Spratly consisting of c. 170 islands scattered over the area of 160$180 \mathrm{~km}^{2}$, and the Paracel archipelago comprising c. 15 islands whose surface area is nearly $8 \mathrm{~km}^{2}$ as well as 12 reefs scattered on the area of 7,500 $\mathrm{km}^{2}$, which makes them an attractive piece to fight for (Kościelniak, 2014, p.11). Therefore, it is not surprising that the Paracel Islands are the subject of dispute between China Vietnam, the Philippines and Malaysia, while as regards the Spratly Islands, claims are made by China, Taiwan, Vietnam, the Philippines, Malaysia, Singapore and Indonesia. In both cases, China invokes history, indicating that it was the Chinese who were the first to settle on these islands, and for that reason have the right to exercise sovereign authority over the Sea and exploit its resources. In the conflict over the Spratly Islands Vietnam makes reference to history as well, questioning the argument of the Chinese as the first settlers. The remaining states claim their rights to smaller parts of the archipelago: Malaysia to its southern part which belongs to its economic zone, the Philippines to the islands located in the area called Kalayaan, while the sultanate of Brunei strives for the area contained in its economic zone, etc. (Kościelniak, 2014, pp. 11-19). Nonetheless, it is not the end of the disputable subjects' list, since another problematic issue is the right to exploit the resources from the seabed. The estimated volume of the deposits differs considerably depending on the source, e.g. according to the U.S Energy Information Agency, the seabed has c. 11 billion barrels of oil and 190 trillion cubic feet of natural gas, while China National Offshore Oil Company (CNOOC) claims that the area holds around 125 billion barrels of oil and 500 trillion cubic feet of natural gas ( $O$ co toczy się spór..., 2015). The South China Sea body of water has not been thoroughly explored yet, and therefore it is difficult to assess the actual volume of the re- 
sources its seabed holds. However, the fact remains that the state which would gain the right to exploit them, would become less dependent on external supplies (O co toczy się spór..., 2015). The coast of the South China Sea is inhabited by considerable population of people who take advantage of the abundant fish and seafood these waters provide. The disputed archipelagos in the South China Sea are located in the direct neighbourhood of the marine shipping routes (Sea Lanes of Communication, SLOC) connecting Southeast and East Asia with the Indian Ocean and the Middle East. It is estimated that the number of trading vessels crossing this sea annually is twice as large as on the Suez Canal and three times larger than on the Panama Canal. In total, c. 15\% of the world trade volume cross the South China Sea body of water. For the states like the PRC or Japan, marine supply lines crossing the South China Sea are of strategic significance, since c. $39 \%$ of Japan's whole foreign trade and c. $27 \%$ of the Chinese foreign trade is transported across this sea. Therefore, solving disputes over the islands in the South China Sea employing both the peaceful the military means is quite unlikely. The agreement of the parties would mean a waiver of claims of one of the states and an image failure. And despite the relations between the states happen to be strained, armed confrontation is also improbable. For China, the conflict might be synonymous with deteriorating their position on the international arena, which would mean inhibiting the economic growth. The remaining states also would not benefit from the conflict, because China, as the stronger party would probably defeat them. Even if the remaining states were successful after creating a coalition against China, their economies might be negatively affected. The result of war damage would be an economic downturn, which definitely is not the intention the states in the region (despite the fact all of them are getting armed) (Stach, 2015, pp. 85-119; Kościelniak, 2015, pp. 148-165). The issues related to this body of water are extremely complex. Obviously, an armed conflict can occur there, yet apparently the states of the region will not strive to such solution.

In the following text, we only indicate China's presence on the South China Sea and its consequences. It should be emphasized that the PRC is an economic and military superpower, as well as the most populous country in the world, nevertheless, as regards military issues, it does not equal the United States yet. Pursuing its goals, China has undertaken to build modern naval fleet in order to secure its marine interests, e.g. on the South China Sea, through which $\$ 5.3$ 
trillion worth of commodities and raw materials transits annually (Chiny chca wyprzeć USA..., 2017; Spór o Morze Południowochińskie...., 2017 ). China has been expanding its navy for many years (Bojko, Piwnicki, 2010, pp. 107-137), to facilitate implementing the adopted strategy.

In Beijing's terminology, the islands located between China and the Pacific Ocean are called the first island chain. In the same waters, the so-called Nine-Dash Line was also drawn, demarcating the territory claimed by China. It has been extended quite recently with a "new", tenth dash which symbolises Taiwan. Thereby, China intends to secure itself the control over these waters, through which the most significant maritime transport routes run: "This route, widely available in conflict-free times, can be easily blocked during the war in many areas, thus cutting China off the rest of the world" (Dlaczego Chinom zależy..., 2017). This single sentence characterises Beijing's actions aimed at preventing the possible maritime blockade of the People's Republic of China. Therefore, China has undertaken to build artificial islands, utilizing coral reefs which hardly appeared above the sea level. China has already built 7 artificial islands in the area of the disputed Spratly archipelago and converted them into military outposts with airports, radars and missile defence installations (Chiny nie wezma udziału..., 2018; Spór o Morze Południowochińskie..., 2017). According to the Chinese authorities these actions, conducted on a large scale, have enormous strategic importance for China's future and security. It also appears that the PRC intends to transform these islands into military bases and tourist resorts, and some even believe it is a part of a bigger plan of supremacy on the seas and oceans. However, is the domination on the seas really the point, or is it rather about securing the state's interests in this body of water? If tourists from all over the world arrive there, will any parties decide to attack these islands and expose themselves to the reprisal of the remaining world superpowers?

The best example of how quickly and effectively China reach accomplishes its objectives is one of the previously barren islets to be found on the South China Sea. Within 5 years, nearly 140,000 trees were planted and they are being constantly cared for by specialists. A nature reserve was established on the island to protect sea turtles and other endemic organisms (Chiny zmienity $w$ raje..., 2018). The youngest Chinese city, Sansha, is also being built there, administering the Paracel Islands, Zhongsha and Spratly Islands and their territorial waters. This city has the smallest land area in China - it covers just 13 
square kilometres - but within its administrative boundaries there are also over 2 million square kilometres of waters. It should be emphasized that until now, only fishermen lived in the area in wooden huts on the water. However, it is to change in the future, since China wants the islands to attract tourists, which entails building three airports, five lighthouses and - obviously - military bases for protection (Chiny zmienity w raje..., 2018). As it was related in the media, on $21^{\text {st }}$ May 2018 the Chinese air force practiced landing and takeoff on the islands and reefs on the South China Sea. Among others, Chinese strategic bombers Xian H-6K took part in the manoeuvres, which was obviously noticed by the Philippines, whose Department of Foreign Affairs issued an announcement saying: "We are taking the appropriate diplomatic action necessary to protect our claims and will continue to do so in the future." However, the President of the Philippines, Rodrigo Duterte "[...] has repeatedly announces tightening contact with China and stressed he would not risk a confrontation with China. He also reiterated openness to joint exploration and development in waters believed to be rich in oil and natural gas" (Chińskie bombowce na sztucznych wyspach..., 2018). The states of the region obviously oppose Beijing's actions, but on the other hand, in order not to jeopardise their different interests, they come to terms with these movements, and they even express readiness to cooperate.

According to Anthony Saich, the director of the Ash Center for Democratic Governance and Innovation at Harvard University, Beijing employs the 'carrot and stick' policy towards its neighbours. The 'carrot' are the investments connected to the global initiative "One Belt, One Road" promoted by President Xi Jinping, intended to build logistics infrastructure between China and the states of Asia, Europe and Africa (Chiny zwiększają obecność marynarki..., 2017). The 'stick' are the 'aggressive' movements on the East China Sea and the South China Sea, which raise concerns of different states, e.g. Vietnam and Japan, and (in the judgment of Saich) cause tensions in the relations with the United States. The most disconcerting issue for these states is the development of the navy by Beijing, and - consequently - the expansion of the Chinese presence on the local water bodies.

According to the observers, majority of the Chinese state-of-the-art atomic submarines station in Yulin navy base in the island province Hainan on the South China Sea. Building the artificial islands in the area serves especially the protection of the navy and expanding the range of the Chinese aircraft (Chiny 
zwiększaja obecność marynarki..., 2017). With the aim of improving the effectiveness of the navy, China established a rescue unit which is to increase the combat readiness of the Chinese submarines in the South China Sea (Chiny zwiększają obecność marynarki..., 2017). Its chief task will be conducting rescue operations in the case submarines encounter any problems. Constructing a rescue ship does not seem dangerous, yet according to Shanghai-based commentator of military affairs Ni Lexiong, creating a rescue unit proves that the Chinese navy conducts more operations in the area: "It is a sign that the fleet is getting itself more ready for battle. When the army is stressing more on combat readiness, how can a navy fleet not be equipped with a rescue unit? Rescue squadrons are crucial in war" (China's South Sea Fleet..., 2017). Definitely, such units are essential during the war, but also in peacetime, when the submarines patrol territorial waters. The fact that China launched such unit does not prove anything, while in the opinion of this commentator it is the first step towards war (how shortsighted!).

China also works on sea-based anti-ballistic missile systems: "China's seabased anti-ballistic missile system is intended to protect both its territory and its foreign interests, since the sea-based systems will be deployed wherever its warships arrive. [...] In the first row, they will appear in the region of Asia and the Pacific, and in the Indian Ocean, to protect their interests overseas" (Chiny pracuja nad morska tarcza..., 2018). Commentators draw the attention to the fact that China is attempting to create blue-water naval forces which could secure their interests in the global scale. A parallel can be made to the United Kingdom and the United States, which also have such forces to protect their affairs all over the world. China, being a resilient economy, needs resources which are imported from different parts of the world; to ensure they will reach their destination, it wishes, just as other states, for their interests to be secured. Therefore, China has developed a new sea-based anti-ballistic missile system HQ-26, equipped with cruise missiles with the range of 3,500 km. Such system is to be installed on the type 055 destroyer, the largest Chinese ship of this class, sometimes classified as a cruiser because of the size (Chiny pracuja nad morska tarcza..., 2018). It was probably the reason why the United States did not invite China to participate in RIMPAC international maritime warfare exercise which took place in the summer of 2018 (Chiny nie wezma udziału..., 2018). Further, it ought to be noted that China has carried out more regular aerial patrols over 
the South China Sea. Moreover, introducing into service the new Chinese J-20 stealth fighter aircrafts and carrying out exercise with Su-35 (purchased from Russia) above exactly this body of water prove - according to commentators - a "considerable increase" in the defensive potential of the Chinese air forces (Chiny: lotnictwo będzie częściej..., 2018). In the opinion of Shanghai-based military expert Ni Lexiong, cited by the South China Morning Post, the recent progress announced by China was aimed at demonstrating its capabilities and "surprising foreign countries, especially the United States". He also added: "These jets are now ready years ahead of when the United States was expecting them to be. This is going to deter the US and it also means China is prepared as relations with the US become more tense" (New fighter jets..., 2018).

Making reference to Chinese experts, the Global Times assessed American operations in the South China Sea to be provocations directed at China's sovereignty. Experts warned that the US, whose ultimate goal is to maintain its dominance in the Asia-Pacific region, could endanger the region's stability. Chen Xiangmiao, an expert and a research fellow at the National Institute for the South China Sea said: "China should install more military facilities, such as radar, aircraft and more coastguard vessels in the South China Sea to cope with provocative moves by the US." The relations between the USA and China are becoming increasingly tense, among others due to the tough stance of President Donald Trump's administration as regards trade issues. According to Reuters, there are growing concerns that the disputed water body might become the trigger point (More military facilities..., 2018; Lotniskowiec na spornych wodach..., 2018). China wants to demonstrate that - having large and still growing economy - they invest in armed forces and no one can interfere with that. In mid-April 2018 the largest parade of the Chinese navy in history took place on the South China Sea. According to commentators, exercises in the Taiwan Strait, not announced beforehand, are to send a signal to the government in Taipei, but also be a gesture of geopolitical support for Russia during tensions between Moscow and Washington related to the conflict in Syria (Chiny pręża muskuty..., 2018).. Macau-based military expert Antony Wong Dong, cited in the South China Morning Post, said: "It's very likely that as Russia's strategic partner, China [is using its] navy to show its political support to Russia at such a sensitive moment" (China announces surprise live-fire..., 2018). According to the reports of the Chinese press, the parade on the South China 
Sea involved over 10,000 soldiers and sailors, 76 fighters and nearly 50 surface and underwater vessels (Chiny pręża muskuły..., 2018)., including the Liaoning, the only Chinese aircraft carrier (China announces surprise live-fire..., 2018). Song Zhongping, a military expert told the Global Times that the largest parade in history could also serve as a deterrent to "maritime hegemony" (having the USA in mind), and will make the adversaries think twice before attempting to harm China's core national interests. He also noted that the US aircraft carrier USS Theodore Roosevelt had operated in the South China Sea not long before (China's largest maritime military parade.., 2018). China has been protesting for a long time against the operations carried out on the disputed water body by the Americans. In turn, Washington criticises the development of the Chinese military installations and artificial islands, and calls the US patrols in the region "freedom of navigation operations." Li Jie, a Beijing-based naval expert, claims that organising the parade on the South China Sea was a strategic movement, taking into account that this body of water is a potential area of an armed conflict (Chiny pręża muskuly..., 2018). Looking at the situation, one has the impression that both Cina and the US exchange 'virtual blows' with each other. The question is, who is provoking whom? For instance, at the end of May 2018, American warships entered the waters of the South China Sea, sailing close to the Paracel Islands (Amerykańskie okręty wojenne..., 2018). „Reuters notes that although Sunday operation had been planned for months in advance and the United States regularly carry out the freedom of navigation operations, this time they were conducted at a vulnerable moment" (meaning the days after the invitation to the RIMPAC naval drill had been withdrawn. Is the USA anxious of losing their dominant position in the region? In response to this 'incident' the Chinese Ministry of Foreign Affairs replied that "[...] China has the sovereign rights to the South China Sea". Furthermore, the Chinese Ministry of National Defense declared that "closing the door" does not facilitate building mutual trust and military cooperation between the USA and China (Amerykańskie okręty wojenne..., 2018). An armed conflict in the region is possible, but (as it has already been emphasized), it is not in China's interest. The presence of the American units does not affect Beijing's interests and its established position in any way; however, removing China e.g. from the artificial islands is impossible without resorting to force. What is interesting, at the beginning of June 2018, during the Shangri-La Dialogue conference in Sngapore, the US Secretary of 
Defense James Mattis commented that, China's actions in the disputed regions of South China Sea are "tied directly to military use for the purposes of intimidation and coercion", adding that if needed, the United States will respond decidedly (Sekretarz obrony USA..., 2018; Remarks by Secretary Mattis..., 2018). In turn, the representative of China on this conference, general He Lei said that the islands in the South China Sea belong to China, and "deploying weapons and soldiers on the islands of the South China Sea is also a symbol of China's sovereignty," adding that any state which makes uproar about it is perceived by China as attempting to interfere in the internal affairs of this country (Sekretarz obrony USA..., 2018). Another incident involving American warships took place at the beginning of October 2018, and met with a firm reaction of the People's Republic of China Ministry of National Defense who condemned the fact that an American destroyer sailed too close the disputed islands: "The US side repeatedly sends military ships without permission into seas close to South China Seas islands, seriously threatening China's sovereignty and security, seriously damaging Sino-US military ties and seriously harming regional peace and stability" (China condemns U.S..., 2018). The relations between Beijing and Washington are now (October 2018) very tense because of a trade war in which they have imposed increasingly severe tariffs on each other's imports, as well as the development and expansion of Chinese army and navy resulting in China's increasing maritime activity.

The USA has repeatedly expressed concern with China's military expansion on the South China Sea which in the opinion of Washington can undermine the freedom of navigation in this water body. The American navy carries out missions in the South China Sea, which they call "freedom of navigation operations” (Chiny: lotnictwo będzie częściej patrolować..., 2018). However, China has already taken over the control over a major part of this body of water, accomplishing it with the use of means and in the steps which were not serious enough to provoke a reaction of the United States. The situation was noticed by the Financial Times, which wrote that China openly and firmly declare that they “[...] would not yield 'one inch' of the crucial waterway through which $\$ 5$ tn of trade passes annually" (Washington and its allies..., 2018). Further, we read that "It is another arena in which the waning of US power and of the Pax Americana, which has largely kept the peace and helped fuel Asia's rise to prosperity, have been laid bare." The author of the article is aware that an armed conflict is 
out of the question, but remarks that the USA should not accept the so-called "creeping Chinese hegemony" and ought to intensify the freedom of navigation operations, yet predicting the new order will begin. While reading these words, one question comes to mind - does China really strive for closing this water body for navigation? It appears improbable, exactly due to the fact that raw materials and goods are transported to China and the Chinese products are sent across this sea. The freedom of navigation will be maintained, with the difference that the Americans who ensure the "freedom of navigation" will be replaced by the Chinese, who will not allow their economy to suffer (which would also be undesirable for many states in the world).

It is an undeniable fact that the Chinese air forces and navy intensified their activities near Taiwan and fortified patrols around the island at the beginning of 2018, which some commentators consider to be the element of preparation for an armed conflict. The authorities of Taiwan assessed the exercise of the Chinese army in the strait as an attempt of terrifying the inhabitants of the island and inflaming the situation. Taiwanese Ministry of National Defense announced that on the then oncoming drill the island's army would practice defence from a simulated invasion (Chiny zapowiadaja więcej działań..., 2018). For the states of the region, as well as the USA, expansion of aircraft carriers is also unsettling. According to information from $24^{\text {th }}$ April 2018, the second carrier of the Chinese navy, which is the first such warship domestically produced in the Middle Kingdom, left the docks in the norteastern city of Dalian in Liaoning province. The 001 A type vessel had its first sea trials (Chiny rozpoczynaja testy..., 2018). Launching the 001A type aircraft carrier, which did not have a name then, coincides the $69^{\text {th }}$ anniversary of creating the navy of the PRC.

Undoubtedly, the South China Sea is the key to the region, not only because of maritime communication routes localised there. The issue which is equally or even more significant is the fact that whichever country will manage to gain supremacy over this body of water, will be in control of the entire region. It is definitely the desire of domination that is the main reason for the dispute in the South China Sea, which will not be resolved in the near future. But the victor of the dispute is China, which commenced the work on s satellite surveillance system, including the ships sailing there (Satelitarne oko Chin..., 2018). The first three out of ten satellites of the system are to be launched in the second half of 2019, and will be equipped with cameras and vessel identification technol- 
ogy. The system will reach full capacity in 2021. Such system has enormous significance for commercial shipping and its security, as well as for the army and navy. Obviously, the state which had dominant position and the monopoly for securing the region so far - namely, the United States - does not approve of such control. As Małgorzata Pietrasiak emphasises, "The South China Sea has supra-regional significance, it is global. The conflict escalating around the control over the zones of this sea is very difficult to resolve, mainly due to the fact that the two world superpowers, the United States and China, are involved in it. The USA obviously is not a party of the conflict directly, yet it has an interest in maintaining the freedom of navigation, and therefore they are indirectly engaged in the dispute" (Podsumowanie debaty..., 2018). And Paweł Behrendt pointed out that "The islands of the South China Sea are a gateway to the world for China, and the Middle Kingdom's global ambitions depend on the control over them, therefore we might expect that the rivalry for the supremacy in the region will not come to an end" (Podsumowanie debaty..., 2018). We must agree with that - open war will not break out.

The rivalry over this body of water will not cease to exist, incidents with the use of means of combat are definitely possible, but the states will think twice (or at least we can hope so) before they resort to using force with the aid of their 'military assets. China will definitely not abandon the South China Sea, and one might even claim that their presence will even increase. And all this will happen in the name of securing China's interests, with the superpower ambitions in the background.

\section{BIBLIOGRAPHY:}

Amerykańskie okręty wojenne u wybrzeży Chin. Celem sporne wyspy na Morzu Południowochińskim (2018). Downloaded from: https://nczas.com/2018/05/27/ amerykanskie-okrety-wojenne-u-wybrzezy-chin-celem-sporne-wyspy-na-morzu-poludniowochinskim/.

Bojko J., Piwnicki G. (2010). Mocarstwowa polityka Chin na morzach Azji Południowo-Wschodniej. In: J. Marszałek-Kawa (ed.). Chiny supermocarstwem XXI wieku? Rozważania na temat polityki i gospodarki Państwa Środka (pp. 107-137.). Toruń: Wydawnictwo Adam Marszałek.

China announces surprise live-fire Taiwan Strait drills after massive navy parade 
(2018). Retrieved from: https://www.scmp.com/news/china/diplomacy-defence/article/2141505/surprise-move-china-mount-live-fire-navy-drills-taiwan, China condemns U.S. for South China Sea freedom of navigation operation (2018). Downloaded from: https://uk.reuters.com/article/uk-usa-china-military/chinacondemns-u-s-for-south-china-sea-freedom-of-navigation-operation-idUKKCN1MC04T.

China's largest maritime military parade showcases aircraft carrier battle group (2018). Downloaded from: http://www.globaltimes.cn/content/1097699.shtml. China's South Sea Fleet gets new unit as military looks to boost its presence in disputed waters (2018). https://www.scmp.com/news/china/diplomacy-defence/ article/2116412/chinas-south-sea-fleet-gets-new-unit-pla-looks-boost.

Chińskie bombowce na sztucznych wyspach. Filipiny "podjęły działania” (2018). Downloaded from: https://www.tvn24.pl/wiadomosci-ze-swiata,2/morze-poludniowochinskie-chinskie-bombowce-na-sztucznych-wyspach,838764.html. Chiny chca wyprzeć USA z Morza Południowochińskiego. Mocna deklaracja (2018). Downloaded from: https://www.tvp.info/33360485/chiny-chca-wyprzec-usa-zmorza-poludniowochinskiego-mocna-deklaracja.

Chiny kontroluja już znaczną część Morza Południowochińskiego (2018). Downloaded from: http://www.gospodarkamorska.pl/MW,Sluzby-Morskie/ft:-chinykontroluja-juz-znaczna-czesc-morza-poludniowochinskiego--.html.

Chiny nie wezma udziału w manewrach na Pacyfiku. W tle spór o Morze Południowochińskie (2018). Downloaded from: https://www.defence24.pl/chiny-nie-wezma-udzialu-w-manewrach-na-pacyfiku-w-tle-spor-o-morze-poludniowochinskie 25.

Chiny pracuja nad morska tarcza antyrakietowa (2018). Downloaded from: http:// www.gospodarkamorska.pl/MW,Sluzby-Morskie/media:-chiny-pracuja-nadmorska-tarcza-antyrakietowa--.html.

Chiny pręża muskuly: Największa w historii parada marynarki wojennej (2018). Downloaded from: http://www.gazetaprawna.pl/artykuly/1117296,chiny-zapowiadaja-manewryw-ciesninie-tajwanskiej-i-zaogniaja-konflikt-na-morzu-poludniowochinskim.html.

Chiny rozpoczynaja testy drugiego lotniskowca (2018). Downloaded from: http:// www.defence24.pl/chiny-rozpoczynaja-testy-drugiego-lotniskowca.

Chiny zapowiadaja więcej działań wokół Tajwanu (2018). Downloaded from: http:// www.defence24.pl/chiny-zapowiadaja-wiecej-dzialan-wokol-tajwanu-walki-zpanstwem-islamskim-w-egipcie.

Chiny zmienity w raje sporne wyspy na Morzu Południowochińskim (2018). Downloaded from: http://www.geekweek.pl/aktualnosci/32104/chiny-zmienily-wraje-sporne-wyspy-na-morzu-poludniowochinskim. 
Chiny zwiększaja obecność marynarki na Morzu Południowochińskim (2018). Downloaded from: http://gosc.pl/doc/4265983.Chiny-zwiekszaja-obecnoscmarynarki-na-Morzu-Poludniowochinskim.

Chiny: lotnictwo będzie częściej patrolować Morze Południowochińskie (2018). Downloaded from: http://www.gospodarkamorska.pl/MW,Sluzby-Morskie/ chiny:-lotnictwo-bedzie-czesciej-patrolowac-morze-poludniowochinskie-. html.

Chiny: Resort obrony potępił działania USA na Morzu Południowochińskim (2018). Downloaded from: http://www.gazetaprawna.pl/artykuly/1284657, chiny-resort-obrony-potepil-dzialania-usa-na-morzu-poludniowochinskim.html. Dlaczego Chinom zależy na kontrolowaniu Morza Południowochińskiego (2018). Downloaded from: https://businessinsider.com.pl/polityka/morze-poludniowochinskie-przyczyny-konfliktu-spor-o-dominacje/85tyljc.

Kościelniak, K (2015). Modernizacja sił zbrojnych Socjalistycznej Republiki Wietnamu w XXI wieku. In: J. Marszałek-Kawa (ed.). Bezpieczeństwo współczesnej Azji (pp. 148-165). Toruń: Wydawnictwo Adam Marszałek.

Kościelniak, K. (2011). Przyczyny konfliktów zbrojnych w Azji Południowo-Wschodniej po 1945 roku. In: J. Marszałek-Kawa (ed.). Zagrożenia dla bezpieczeństwa międzynarodowego w XXI wieku. Azjatycka perspektywa (pp.8-27). Toruń: Wydawnictwo Adam Marszałek.

Kościelniak, K. (2012). Stosunki chińsko-wietnamskie po 1945 roku i ich wpływ na bezpieczeństwo wewnętrzne Wietnamu w XXI wieku. In: J. Marszałek-Kawa, R. Gawłowski (eds.). Ewolucja azjatyckiej polityki bezpieczeństwa (pp.38-59). Toruń: Wygawnictwo Adam Marszałek.

Kościelniak, K. (2013). Current International Situation in the South China Sea The Path to Confrontation? Reality of Politics. Estimates - Comments - Forecasts, 4 , pp. 138-149.

Kościelniak, K. (2014). The background of the disputes over the South China Sea islands. Reality of Politics. Estimates - Comments - Forecasts, 5, pp. 11-19.

Kościelniak, K. (2016). Międzynarodowe implikacje sporu na Morzu Południowochińskim. In: J. Marszałek-Kawa, R. Gawłowski (eds.). Polityka bezpieczeństwa w regionie Azji i Pacyfiku (pp.112-127). Toruń: Wydawnictwo Adam Marszałek.

More military facilities should be installed in S. China Sea to counter US provocations: analysts (2018). Downloaded from: http://www.globaltimes.cn/content/1090627.shtml.

New fighter jets will be used in 'more regular' patrols over South China Sea (2018). Downloaded from: https://www.scmp.com/news/china/diplomacy-defence/ article/2133236/new-fighter-jets-will-be-used-more-regular-patrols-over. 
O co toczy się spór na Morzu Południowochińskim? (2018). Downloaded from: http:// www.psz.pl/123-bezpieczenstwo/o-co-toczy-sie-spor-na-morzu-poludniowochinskim.

Podsumowanie debaty „Morze Południowochińskie a bezpieczeństwo $w$ regionie Azji i Pacyfiku" (2018). Downloaded from: http://www.polska-azja.pl/podsumowanie-debaty-morze-poludniowochinskie-a-bezpieczenstwo-w-regionieazji-i-pacyfiku/.

Remarks by Secretary Mattis at Plenary Session of the 2018 Shangri-La Dialogue (transcript) (2018), Downloaded from: https://dod.defense.gov/News/Transcripts/Transcript-View/Article/1538599/remarks-by-secretary-mattis-at-plenary-session-of-the-2018-shangri-la-dialogue/.

Rowiński, J. (1990). Morze Południowochińskie - region potencjalnego konfliktu w Azji, Warszawa: Wydawnictwo PISM.

Satelitarne oko Chin na Morze Południowochińskie (2018), Downloaded from: https://www.space24.pl/satelitarne-oko-chin-na-morze-poludniowochinskie.

Sekretarz obrony USA: działania Chin na Morzu Południowochińskim służa zastraszaniu (2018), Downloaded from: https://www.polskieradio.pl/5/3/ Artykul/2138932,Sekretarz-obrony-USA-dzialania-Chin-na-Morzu-Poludniowochinskim-sluza-zastraszaniu.

Spór o dalekowschodnie wyspy Lotniskowiec na spornych wodach. Krytyka w Chinach, prasa chce zbrojeń (2018). Downloaded from: https://www.tvn24.pl/wiadomosci-ze-swiata,2/morze-poludniowochinskie-chiny-reaguja-na-cwiczenialotniskowca-usa,818163.html.

Spór o Morze Południowochińskie. Paweł Behrendt dla Onetu: Chiny prężą muskuły (2018). Downloaded from: https://wiadomosci.onet.pl/tylko-w-onecie/ spor-o-morze-poludniowochinskie-pawel-behrendt-dla-onetu-chiny-prezamuskuly $/ 450 x 5 \mathrm{~kg}$.

Stach, Ł. (2015). Małe, ale czy niegroźne? Floty wojenne mniejszych krajów Azji Południowo-Wschodniej. In: J. Marszałek-Kawa (ed.). Bezpieczeństwo współczesnej Azji (pp. 85-119), Toruń: Wydawnictwo Adam Marszałek.

Washington and its allies need to contain Beijing (2018), Downloaded from: https:// www.ft.com/content/fe1e25fa-7bbc-11e8-8e67-1e1a0846c475. 